medRxiv preprint doi: https://doi.org/10.1101/2021.11.10.21266141; this version posted November 10,2021 . The copyright holder for this preprint (which was not certified by peer review) is the author/funder, who has granted medRxiv a license to display the preprint in

It is made available under a CC-BY 4.0 International license .

\title{
PBPK modelling of dexamethasone in patients with COVID-19 and liver disease
}

Maiara Camotti Montanha, Ph.D. ${ }^{1}$, Nicolas Cottura, PharmD ${ }^{1}$, Michael Booth, MSc. ${ }^{1}$, Daryl

Hodge, Ph.D. ${ }^{1}$, Fazila Bunglawala, MSc. ${ }^{1}$, Hannah Kinvig, Ph.D. ${ }^{1}$, Sandra Grañana-Castillo ${ }^{1}$, Andrew Lloyd ${ }^{1}$, Saye Khoo, M.D. ${ }^{1}$, Marco Siccardi, Ph.D. ${ }^{1}$.

${ }^{1}$ Department of Pharmacology and Therapeutics, Institute of Systems, Molecular and Integrative Biology, University of Liverpool, Liverpool, United Kingdom

Author for correspondence: Dr. Maiara Montanha, Department of Pharmacology and Therapeutics, Institute of Systems, Molecular and Integrative Biology, University of Liverpool, 70 Pembroke Place, Liverpool, L69 3GF, U.K.

Tel No +44 (0) 1517948211

Fax No + $44(0) 1517945656$

E-mail: M.camotti-montanha@liverpool.ac.uk

\section{Conflict of interest}

M.S. has received research grant funding from Janssen and ViiV. S.K. has received research grants from ViiV, Gilead, Merck and Janssen. The other authors do not have any conflict of interests.

\section{Funding}

This project is funded by a research grant awarded by the UKRI (MRC) and the DHSC (NIHR), grant reference: MR/V020498/1.

\section{Keywords}

Dexamethasone, Liver disease, COVID-19, PBPK modelling 
medRxiv preprint doi: https://doi.org/10.1101/2021.11.10.21266141; this version posted November 10,2021 . The copyright holder for this preprint (which was not certified by peer review) is the author/funder, who has granted medRxiv a license to display the preprint in

It is made available under a CC-BY 4.0 International license.

\begin{abstract}
The aim of the study was to apply Physiologically-Based Pharmacokinetic (PBPK) modelling to predict the effect of liver disease (LD) on the pharmacokinetics (PK) of dexamethasone (DEX) in the treatment of COVID-19. A whole-body PBPK model was created to simulate 100 adult individuals aged 18-60 years. Physiological changes (e.g., plasma protein concentration, liver size, CP450 expression, hepatic blood flow) and portal vein shunt were incorporated into the LD model. The changes were implemented by using the Child-Pugh (CP) classification system. DEX was qualified using clinical data in healthy adults for both oral (PO) and intravenous (IV) administrations and similarly propranolol (PRO) and midazolam (MDZ) were qualified with PO and IV clinical data in healthy and LD adults. The qualified model was subsequently used to simulate a $6 \mathrm{mg}$ PO and $20 \mathrm{mg}$ IV dose of DEX in patients with varying degrees of LD, with and without shunting. The PBPK model was successfully qualified across DEX, MDZ and PRO. In contrast to healthy adults, the simulated systemic clearance of DEX decreased $(35 \%-60 \%)$ and the plasma concentrations increased $(170 \%-400 \%)$ in patients with LD. Moreover, at higher doses of DEX, the AUC ratio between healthy/LD individuals remained comparable to lower doses. The exposure of DEX in different stages of LD was predicted through PBPK modelling, providing a rational framework to predict PK in complex clinical scenarios related to COVID-19. Model simulations suggest dose adjustments of DEX in LD patients are not necessary considering the low dose administered in the COVID-19 protocol.
\end{abstract}


medRxiv preprint doi: https://doi.org/10.1101/2021.11.10.21266141; this version posted November 10,2021 . The copyright holder for this preprint (which was not certified by peer review) is the author/funder, who has granted medRxiv a license to display the preprint in

It is made available under a CC-BY 4.0 International license .

\section{INTRODUCTION}

Chronic liver disease (LD) is prevalent in 3 to $8 \%$ of patients suffering with COVID-19. ${ }^{1}$ Chronic LD has been associated with a higher rate of mortality in COVID-19 patients and can affect the drug distribution of several treatments. ${ }^{2}$ End stage chronic liver disease leads to cirrhosis which is characterised by the replacement of injured tissue with a collagenous scar and is accompanied by a loss of functional hepatocytes as well as a distortion in hepatic vasculature. ${ }^{3,4}$ The severity of liver disease can be classified using the $\mathrm{CP}$ score $\mathrm{A}, \mathrm{B}$, and $\mathrm{C}$ and is based on physiological and biological parameters. ${ }^{5}$ As the severity of liver disease increases, the distortion of the hepatic vasculature may lead to portal hypertension and in turn portacaval shunting. Shunting can significantly increase the bioavailability of a drug due to a decrease in first pass metabolism and this effect can be particularly relevant for drugs with a high first-pass extraction. ${ }^{6}$

DEX is a corticosteroid traditionally used in a wide range of conditions such as rheumatic or endocrine disorders for its anti-inflammatory and immunosuppressant effects, ${ }^{7}$ and can be used as a treatment for patients with severe COVID-19 disease. ${ }^{8}$ DEX has a relatively low hepatic extraction and is metabolised by the cytochrome P450 (CYP) enzymatic system, primarily by the CYP3A4 isoform, of which it is also a weak-moderate inducer. ${ }^{7,9,10}$ A previous study study showed reduced DEX clearance $(\mathrm{CL})$ and prolonged half-life $\left(\mathrm{t}_{1 / 2}\right)$ in individuals with LD compared with that in healthy subjects. ${ }^{11}$ However, DEX plasma concentrations, different forms of administration and detailed description of the individuals included in the study (e.g., LD severity according to $\mathrm{CP}$ score) are lacking.

PBPK modelling is a simulation approach with multiple applications and which is accepted by regulatory agencies primarily to evaluate enzyme-based drug-drug interactions $(60 \%$ of submissions between 2008 and 2017). ${ }^{12}$ PBPK can account for changes in absorption, metabolism, distribution, and elimination (ADME), through the integration of in vitro data 
medRxiv preprint doi: https://doi.org/10.1101/2021.11.10.21266141; this version posted November 10,2021 . The copyright holder for this preprint (which was not certified by peer review) is the author/funder, who has granted medRxiv a license to display the preprint in

It is made available under a CC-BY 4.0 International license.

using in vitro-in vivo extrapolation (IVIVE) techniques for the prediction of PK in a cohort of virtual patients. The effect of liver disease on pharmacokinetics can be simulated considering a number of physiological changes as functional liver size, CYP450 expression, plasma protein binding and hepatic blood flow. ${ }^{3,5}$ The aim of this study was to use PBPK modelling to predict DEX PKs for the treatment of COVID-19 in patients with liver impairment.

\section{METHODS}

A whole body PBPK model constructed using Simbiology v. 5.8.2, a product of MATLAB ${ }^{\circledR}$ R2019a v. 9.6.0 (MathWorks, Natick, MA, USA 2013), was used to generate a cohort of 100 individuals aged 18-60 years (50\% female and 50\% male). The following assumptions were made during simulations: (1) instant and uniform drug distribution (well-stirred model) across each compartment (tissue/organ); (2) no reabsorption of the drug from the colon; and (3) drug distribution was limited by blood flow. No ethical approval was required as results for this investigation were generated virtually.

\section{Anatomy and Physiology}

The body mass index (BMI), body surface area (BSA), height and weight of the individuals were generated as described by de la Grandmaison et al. ${ }^{13}$ These values were used to allometrically calculate organs and tissues volumes through equations described by Bosgra et $a l .{ }^{14}$ Density was used to calculate organs and tissues weights as described by Brown et al. ${ }^{15}$ Blood flows were calculated using percentage regional blood flows of the cardiac output described by the Environmental Protection Agency (EPA). ${ }^{16}$ To represent a LD population, changes to the physiological and biochemical parameters in the healthy adult model were made according to Johnson et al. ${ }^{3}$ The parameters and corresponding values are summarised in Table 1 .

\section{Oral absorption}


medRxiv preprint doi: https://doi.org/10.1101/2021.11.10.21266141; this version posted November 10,2021 . The copyright holder for this preprint (which was not certified by peer review) is the author/funder, who has granted medRxiv a license to display the preprint in

It is made available under a CC-BY 4.0 International license .

Oral absorption was simulated using a compartmental absorption and transit model. ${ }^{14}$ The drug absorption rate constant $\left(K_{\mathrm{a}}\right)$ was calculated using the effective permeability $\left(\mathrm{P}_{\text {eff }}\right)$ based on the in vivo regional jejunal permeability in humans for PRO. ${ }^{17}$ For MDZ and DEX values observed in the literature for $K_{\mathrm{a}}$ were applied. The parameters are described in Table 2.

\section{Intestinal metabolism}

The clearance of MDZ, PRO and DEX in the gut (CLgut) were calculated considering the intrinsic clearance $\left(\mathrm{Cl}_{\mathrm{int}}\right)$ and abundance of the enzyme involved in the metabolism of each drug in the intestinal tissue (Eq. (1)):

$$
\mathrm{CL}_{\text {gut }}=\mathrm{CL}_{\text {intENZYME }} \times \mathrm{Ab}_{\text {ENZYME,gut }} \times \mathrm{MPPGI} \times \mathrm{W}_{\text {intestines }}
$$

Where $\mathrm{CL}_{\text {intENZYME }}$ is the $\mathrm{Cl}_{\text {int }}$ of CYP3A4 for MDZ and DEX, and the $\mathrm{Cl}_{\text {int }}$ of CYP2C19 for PRO, AbenZYME,gut is its relative abundance in the intestinal tissue $\left(\mathrm{Ab}_{\mathrm{CYP} 3 \mathrm{~A} 4 \text {,gut }}=19.2\right.$ $\left.\mathrm{pmol} / \mathrm{mg},{ }^{18} \mathrm{Ab} \mathrm{CYP}_{2 \mathrm{C} 19, \mathrm{gut}}=2.1 \pm 0.1 \mathrm{pmol} / \mathrm{mg}^{19}\right)$, MPPGI is the amount of microsomal protein per gram of intestine $\left(\mathrm{MPPGI}=2.7 \mathrm{mg} / \mathrm{g}{ }^{18}\right.$ ), and $\mathrm{W}_{\text {intestines }}$ is the weight of the intestines. The $\mathrm{Cl}_{\text {int }}$ of each enzyme is described in Table 2. CYP2D6 and CYP1A2 was not considered in the gut for PRO since its contribution to total intestinal CYP is minimal $(<1 \%){ }^{20}$

The fraction of drug escaping gut metabolism and transitioning to the liver $\left(\mathrm{F}_{\mathrm{g}}\right)$ was computed with the following equation (Eq. (2)):

$$
F_{g}=\frac{Q_{\text {gut }}}{\left(Q_{\text {gut }}+\left(f_{u, \text { gut }} \times C L_{\text {gut }}\right)\right.}
$$

Where $\mathrm{Q}_{\text {gut }}$ represents the blood flow to the gut, and $\mathrm{f}_{\mathrm{u}, \mathrm{gut}}$ is the fraction unbound of the drug in the gut, considered equal 1 in the model. ${ }^{21}$

\section{Hepatic metabolism}

Similarly, to the gut, the intrinsic clearance of each enzyme involved in the hepatic metabolism of MDZ, PRO and DEX were scaled up to the whole liver $\left(\mathrm{CL}_{\text {int,liver }}\right)$ considering the equation below (Eq. (3)): 
medRxiv preprint doi: https://doi.org/10.1101/2021.11.10.21266141; this version posted November 10,2021 . The copyright holder for this preprint (which was not certified by peer review) is the author/funder, who has granted medRxiv a license to display the preprint in It is made available under a CC-BY 4.0 International license.

$$
\mathrm{CL}_{\text {int,liver }}=\mathrm{CL}_{\text {intENZYME }} \times \mathrm{Ab}_{\text {ENZYME, liver }} \times \mathrm{MPPGL} \times \mathrm{W}_{\text {liver }}
$$

Where $\mathrm{CL}_{\text {intENZYME }}$ is the $\mathrm{Cl}_{\text {int }}$ of CYP3A4 for MDZ and DEX, and the $\mathrm{Cl}_{\text {int }}$ of $\mathrm{CYP} 1 \mathrm{~A} 2$, CYP2D6, CYP2C19 and UDP-glucuronosyltransferases (UGT) for PRO, AbEnZYME,liver is the abundance of the enzyme in the liver $\left(\mathrm{Ab}_{\mathrm{CYP} 3 \mathrm{~A} 4, \text { liver }}=155 \mathrm{pmol} / \mathrm{mg},{ }^{22} \mathrm{Ab}_{\mathrm{CYP} 1 \mathrm{~A} 2 \text {, liver }}=29.4 \pm\right.$ $29.6 \mathrm{pmol} / \mathrm{mg},{ }^{23} \mathrm{Ab}_{\mathrm{CYP} 2 \mathrm{D} 6, \text { liver }}=11.9 \pm 13.2 \mathrm{pmol} / \mathrm{mg},{ }^{23} \mathrm{Ab}_{\mathrm{CYP} 2 \mathrm{C} 19, \text { liver }}=17.8 \pm 3.3 \mathrm{pmol} / \mathrm{mg}$ ${ }^{24}$ ) and MPPGL is the amount of microsomal protein per gram of liver, $\mathrm{W}_{\text {liver }}$ is the weight of the liver. The $\mathrm{Cl}_{\text {int }}$ of CYP3A4 and CYP2C19 was considered the same in the gut and liver for DEX and PRO, respectively, since no data specific to the gut were available. The intrinsic clearance of CYP3A4 in the gut and liver for MDZ were considered different All parameters

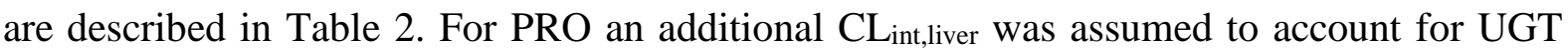
metabolism (Eq. (4)):

$$
\mathrm{CL}_{\text {int,liver }}=\mathrm{CL}_{\text {int, } \mathrm{UGT}} \times \mathrm{MPPGL} \times \mathrm{W}_{\text {liver }}
$$

The MPPGL was calculated according to equation reported by Barter et al (Eq. (5)) ${ }^{25}$ :

$$
\mathrm{MPPGL}=10^{1.407+0.0158 \times \mathrm{XAge}^{2}+0.0000024 \times \mathrm{XAge}^{3}}
$$

The total hepatic intrinsic clearance $\left(\sum \mathrm{CL}_{\text {int,liver }}\right)$ was considered as the sum of all enzymes involved in the metabolism. The hepatic systemic clearance $\left(\mathrm{CL}_{h e p}\right)$ was calculated considering blood flow and the total $\sum \mathrm{CL}_{\text {int,liver }}($ Eq. (6)):

$$
\mathrm{CL}_{\text {hep }}=\frac{\mathrm{Q}_{\mathrm{hv}} \times\left(\sum \text { CLint, liver } \times \mathrm{f}_{\mathrm{up}} / \mathrm{R}\right)}{\mathrm{Q}_{\mathrm{hv}}+\left(\sum \text { CLint, liver } \times \mathrm{f}_{\mathrm{up}} / \mathrm{R}\right)}
$$

Where $Q_{\text {hv }}$ is the hepatic blood flow rate, $f_{u p}$ is the fraction of drug unbound in plasma and $\mathrm{R}$ is the blood to plasma ratio. The fraction of drug that escapes hepatic metabolism and reaches the systemic circulation $\left(F_{h}\right)$ is represented by the following equation (Eq. (7)): 
medRxiv preprint doi: https://doi.org/10.1101/2021.11.10.21266141; this version posted November 10,2021 . The copyright holder for this preprint (which was not certified by peer review) is the author/funder, who has granted medRxiv a license to display the preprint in

$$
\mathrm{F}_{\mathrm{h}}=\frac{\mathrm{Q}_{\mathrm{pv}}}{\mathrm{Q}_{\mathrm{pv}}+\left(\mathrm{CL}_{\text {int,liver }} \times f_{u p} / R\right)}
$$

Where $\mathrm{Q}_{\mathrm{pv}}$ is the blood flow rate of the portal vein.

Given DEX`s auto-induction of CYP3A4, induction of CYP in the intestine and liver were calculated from using the following equation (Eq. (8)):

$$
\operatorname{Ind}_{\mathrm{CYP3A4}(\text { organ })}=1+\left(\frac{\left(\mathrm{E}_{\max } \times \mathrm{C}_{\text {organ,u }}\right)}{\left(\mathrm{EC}_{50}+\mathrm{C}_{\text {organ,u }}\right)}\right)
$$

Where $E_{\max }$ is the maximum enzyme activity, $C_{\text {organ,u }}$ is the average unbound drug concentration in the intestinal and liver tissues and $\mathrm{EC}_{50}$ is the DEX concentration required to reach half of the maximum enzyme activity. Then the $\mathrm{CL}_{\text {gut }}$ and $C \mathrm{CL}_{\text {int,liver }}$ (equations 1 and 3 ) was multiplied by Ind $\mathrm{CYP}_{\mathrm{A} A 4, \text { organ }}$.

Portocaval shunting was incorporated into the LD model by implementing a shunt index that considers the varying levels of shunting associated with the different severities of liver disease as well as the serum total bile acid concentrations in the peripheral vein. ${ }^{26,27}$ The fraction of drug that bypasses the liver due to shunting $\left(\mathrm{F}_{\text {shunt }}\right)$ is represented by the following (Eq. (9)):

$$
\mathrm{F}_{\text {shunt }}=\text { shunt index } \times\left(1-\mathrm{F}_{\mathrm{h}}\right)
$$

\section{Distribution}

Drug distribution was calculated using first-order differential equations, with the volume of distribution $(\mathrm{Vd})$ computed using the tissue to plasma ratio (TP) of each organ and the volume of each organ compartment. ${ }^{28} \mathrm{~A}$ correction factor (Table 2) was applied to the Vd of MDZ and DEX via curve-fitting method to match observed Vd values in the literature. ${ }^{7,29}$ The physiochemical properties of the drugs used in the models are detailed in Table 2.

\section{Elimination}

Elimination of MDZ and PRO were considered as exclusively hepatic however, for DEX an additional renal clearance amounting to $10 \%$ of the systemic clearance was applied in 
medRxiv preprint doi: https://doi.org/10.1101/2021.11.10.21266141; this version posted November 10,2021 . The copyright holder for this preprint (which was not certified by peer review) is the author/funder, who has granted medRxiv a license to display the preprint in

It is made available under a CC-BY 4.0 International license .

accordance with the literature (Table 2). ${ }^{30}$ A liver impairment scaling factor for renal function was applied as described in Table 1.

\section{Model qualification}

The model was firstly qualified for DEX, MDZ and PRO in a healthy population followed by qualification in a LD population for MDZ and PRO. The model qualification was extended to MDZ and PRO as the availability of observed clinical data across CP scores is incomplete and not all stages of LD and shunt index have been fully described. Specifically, MDZ was chosen due to its similarity in metabolic pathway to DEX, as both drugs are predominantly metabolised by CYP3A4. However, PK data for MDZ were not available for LD individuals with different CP scores, so a mixture of patients with different liver disease degrees was used. ${ }^{31}$ Therefore, to validate $\mathrm{CP}-\mathrm{A},-\mathrm{B}$ and $-\mathrm{C}$ and the shunt index incorporated into the LD model individually, PRO was chosen due to the availability of observed clinical data reflecting these scenarios. ${ }^{32}$ A schematic representation of this workflow is shown in Error! Reference source not found.. The model qualification was performed according to recommendations of the European Medicine Agency (EMA) ${ }^{33}$ and was considered validated when the mean of simulated PK parameters for each drug was less than two-fold of the observed clinical mean and the absolute average fold error (AFE) was below $2 .{ }^{34}$ The doses and regimens of the drugs were chosen to reflect the clinical studies used to validate the model. ${ }^{31,32,35}$ Due to the type of clinical data available for MDZ, simulated PK parameters for MDZ in the LD population were calculated considering the mean of conditions $\mathrm{CP}-\mathrm{A},-\mathrm{B}$ and $-\mathrm{C}$ in order to reflect the clinical data sets. For PRO, clinical data were reported for 15 individuals alongside their respective $\mathrm{CP}$ score and shunt index thus, 100 simulations were carried out for each individual with their specific age, weight, CP score and shunt index implemented in the LD model. ${ }^{32}$ The mean PK parameters for PRO across all individuals were also calculated and compared for both simulated and observed clinical data. 
medRxiv preprint doi: https://doi.org/10.1101/2021.11.10.21266141; this version posted November 10,2021 . The copyright holder for this preprint (which was not certified by peer review) is the author/funder, who has granted medRxiv a license to display the preprint in It is made available under a CC-BY 4.0 International license.

\section{Predictions}

The PBPK model was used to predict the PK of DEX in virtual populations with varying degrees of liver disease, classified according to $\mathrm{CP}$ scores (A, B and C). The varying levels of portacaval-shunting associated with liver disease considered in the simulations was an aleatory linearly spaced range with minimum value of 0.1 and maximum value of 0.7 as previously described. ${ }^{26}$

The dosages selected for the simulations were in line with current COVID-19 protocols stipulated by the National Institute for Health and Care Excellence; $6 \mathrm{mg}$ dose once a day PO for 7 - 10 days; $6 \mathrm{mg}$ dose once a day IV for $7-10$ days. ${ }^{36}$ To further evaluate high doses of DEX, simulations with $20 \mathrm{mg}$ were made. The PK parameters were calculated considering steady-state plasma concentration on $10^{\text {th }}$ day in accordance with the COVID-19 protocol.

\section{RESULTS}

\section{Model qualification}

The PBPK model was successfully qualified for all drugs in healthy (MDZ, PRO and DEX) and LD individuals (MDZ and PRO) according to the selected criteria. The simulated and observed PK parameters for each drug as well as the AFE values are presented in Table 3, as previously described. The plasma concentration-time profiles of each drug are described in the supplementary material (Figure S1-S5).

\section{Predictions}

The predicted PKs of DEX are shown in Table 4. The PBPK model for both the PO and IV administration of DEX predicted a decrease in the CL of DEX and increase in plasma concentration of DEX for patients with LD of all CP scores and shunt indexes. However, the exposure of DEX was found to be higher in patients with advanced CP scores, as shown in Figure 2. Furthermore, plasma concentrations of DEX were slightly higher in individuals with portal-systemic shunt compared to individuals with no shunting during PO administration. In 
medRxiv preprint doi: https://doi.org/10.1101/2021.11.10.21266141; this version posted November 10,2021 . The copyright holder for this preprint (which was not certified by peer review) is the author/funder, who has granted medRxiv a license to display the preprint in

It is made available under a CC-BY 4.0 International license .

Table 4, plasma concentrations are expressed as unbound in comparison to total plasma concentration shown in table 3. The shunting index had no effect when DEX was administered IV (Error! Reference source not found.) as the portal-systemic shunt primarily affects firstpass metabolism. When exploring higher doses of DEX it was found that the AUC ratio between healthy and LD individuals remained comparable to lower doses, as described in Table 4.

\section{DISCUSSION}

The clinical management of individuals with LD is challenging. The PK of DEX in LD patients has been partially described through a clinical study, showing a reduced clearance and increased half-life, but no information of total exposure (AUC0-inf) and PK profiles were available. ${ }^{11}$ The PBPK model described herein simulated DEX PK in different stages of LD with various grades of shunting, providing evidence-based guidance towards the clinical management of COVID-19 in LD patients.

Overall, the plasma concentration of DEX is expected to increase with liver impairment. The PBPK model was successfully validated and predicted an increase in AUC0-24 of 172\% (181\% with shunt), 244\% (264\% with shunt), and 376\% (406\% with shunt) compared to healthy individuals for $\mathrm{CP}-\mathrm{A}, \mathrm{CP}-\mathrm{B}$, and $\mathrm{CP}-\mathrm{C}$, respectively when DEX was administered orally. Furthermore, the corresponding clearance values were predicted to decrease approximately $35 \%, 50 \%$ and $60 \%$ in comparison to healthy individuals for $\mathrm{CP}-\mathrm{A}, \mathrm{CP}-\mathrm{B}$, and $\mathrm{CP}-\mathrm{C}$, respectively. The trend for CL to decrease was comparable to that previously found in the DEX clinical trial in LD patients. ${ }^{11}$ Furthermore, although first-pass metabolism can represent a relevant process in DEX PK, the predicted difference in AUC0-24 and CL between IV and PO administrations in LD individuals was minimal and is likely due to the high bioavailability (7078\%) of DEX. ${ }^{7}$ Additionally, first-pass metabolism is thought to be impacted by the shunt 
medRxiv preprint doi: https://doi.org/10.1101/2021.11.10.21266141; this version posted November 10,2021 . The copyright holder for this preprint (which was not certified by peer review) is the author/funder, who has granted medRxiv a license to display the preprint in

effect, increasing a drug's bioavailability, yet the impact of shunting on the AUC0-24 and CL of DEX remained minimal. Simulations of DEX $20 \mathrm{mg}$ IV and PO once a day were made since higher doses are being investigated to present clinical improvement and decrease in inflammatory biomarkers in patients hospitalized with COVID-19, but remain unproven. ${ }^{37}$ However, the AUC ratio between healthy and individuals with LD remained comparable to the lower dose (6 mg once a day), showing linear PK. For this reason, no simulation with shunt effect was performed with the higher dose since the same behaviour of lower dose is expected. According to the FDA and the EMA guidance for industry, PK studies should be conducted in patients with impaired hepatic function to evaluate whether a dose adjustment is necessary, ${ }^{38,39}$ yet the number of drugs that provide this specific recommendation for dosage adjustment based on different hepatic functions is very limited. ${ }^{40}$ This LD PBPK model could be applied to evaluate other drugs for use in COVID-19, such as anticoagulants, other corticosteroids, antiviral agents, antibiotics, anti-inflammatory drugs. ${ }^{41}$

According to the FDA guidelines, dosage adjustments should be recommended when a twofold or greater increase in the AUC is observed. ${ }^{38}$ However, dose adjustment in COVID-19 patients is complex, defining a multifactorial scenario for which polypharmacy and preexisting conditions should be considered alongside the risk of potential drug-drug interactions (DDIs) which may lead to altered PK. Moreover, the use of support resources in the care of COVID-19 patients, such as renal replacement, ventilation, volume replacement, can affect drug ADME generating further complexities in the assessment of dosing strategies. ${ }^{42}$

There are some aspects in the application of DEX for the treatment of COVID-19 that should be considered when analysing the data from this study. Firstly, severe COVID-19 is associated with a systemic hyper=-inflammation state with increased cytokine levels and highly elevated C-reactive protein (CRP) all of which are known to impact drug PK through the downregulation of CYP isoenzymes. ${ }^{43-45}$ The current PBPK model does not incorporate these 
medRxiv preprint doi: https://doi.org/10.1101/2021.11.10.21266141; this version posted November 10,2021 . The copyright holder for this preprint (which was not certified by peer review) is the author/funder, who has granted medRxiv a license to display the preprint in

mechanisms due to limited data/ability to verify the model. Secondly, DEX has been coadministered with tocilizumab for the treatment of COVID-19, however, the DDI between these drugs has not been studied in LD individuals. Tocilizumab has been reported to inhibit interleukin 6 (IL-6), increasing the activity of CYP450 enzymes and therefore producing increased metabolism of drugs that are CYP450 substrates. ${ }^{46}$ This pharmacodynamic DDI may compensate for the decreased CL observed in LD condition. Finally, corticosteroids such as DEX can present side effects relating to the central nervous system. In most cases the side effects occur within the 5 first days of treatment, however, the psychiatric symptoms tend to begin after 11 days and become more pronounced with extended periods of treatment. The psychiatric side effect also appears to be dose-dependent, occurring more often for doses up to $80 \mathrm{mg}$ daily. ${ }^{47}$ Whilst side effects need to be monitored during the administration of DEX, no dose adjustments seem necessary in healthy or LD patients.

Though the PK of DEX in LD was successfully predicted, the model is characterized by some limitations. Although a direct and proportional relationship between CP score and increase in the plasma drug exposure was assume in the model, as demonstrated before by Johnson et al., ${ }^{3}$ and also a linear correlation between portal vein shunt index and serum total bile acid concentrations in the peripheral vein, ${ }^{27}$ outliers individuals will not be represented by this assumption as demonstrated in supplementary table S2. Furthermore, the prevalence of spontaneous portosystemic shunt (SPS) increases as liver function injures, probably as an effect of damaging portal hypertension. ${ }^{26}$ However, large-SPS can be present in CP-A individuals as no SPS or small-SPS can be present in CP-C individuals. ${ }^{26}$ For this reason, the varying levels of portacaval-shunting associated with LD considered in the simulations was an aleatory linearly spaced range between 0.1 and 0.7 . Other factors such as inter-individual variability, polymorphism, age (e.g., propranolol showed greater plasma level in elderly compared to young individuals), ${ }^{48}$ and unknown LD physiopathology mechanisms not represented in the 
medRxiv preprint doi: https://doi.org/10.1101/2021.11.10.21266141; this version posted November 10,2021 . The copyright holder for this preprint (which was not certified by peer review) is the author/funder, who has granted medRxiv a license to display the preprint in

It is made available under a CC-BY 4.0 International license.

model corroborate the challenge of qualifying the LD PBPK model against specific CP classifications.

\section{CONCLUSION}

An increased exposure of DEX across varying stages of LD was predicted using PBPK modelling. Although DEX exposure was predicted to be more than 3 times higher in CP-C individuals, no dose adjustments seem necessary in patients with LD considering DEX's low hepatic extraction, the low dose administered in the COVID-19 protocol and short period of treatment (10 days), and the therapeutic index of DEX. This study provides in silico evidencebased guidance towards the management of complex clinical scenarios related to COVID-19 and provides a rational framework for future PBPK modelling applications in LD patients. Further PBPK modelling initiatives would be necessary to evaluate the net effect of both LD and inflammatory physiological alterations on the PK of drugs used in the treatment of COVID19.

\section{Study Highlights}

- To propose a PBPK model capable of simulating the PK of drugs in LD patients classified according to the Child-Pugh system.

- To integrate portacaval-shunting associated with LD in a PBPK model.

- To predict DEX exposure in LD patients considering the dose administered in the COVID19 protocol.

\section{Author contributions}

All authors contributed to the overall concept of the model. M.C., N.C. and M.B. performed the modelling design, qualification, and application of the model. M.C., M.B. and M.S. wrote 
medRxiv preprint doi: https://doi.org/10.1101/2021.11.10.21266141; this version posted November 10,2021 . The copyright holder for this preprint (which was not certified by peer review) is the author/funder, who has granted medRxiv a license to display the preprint in

It is made available under a CC-BY 4.0 International license.

the manuscript with support from all the other authors. All authors reviewed and contributed to the final manuscript.
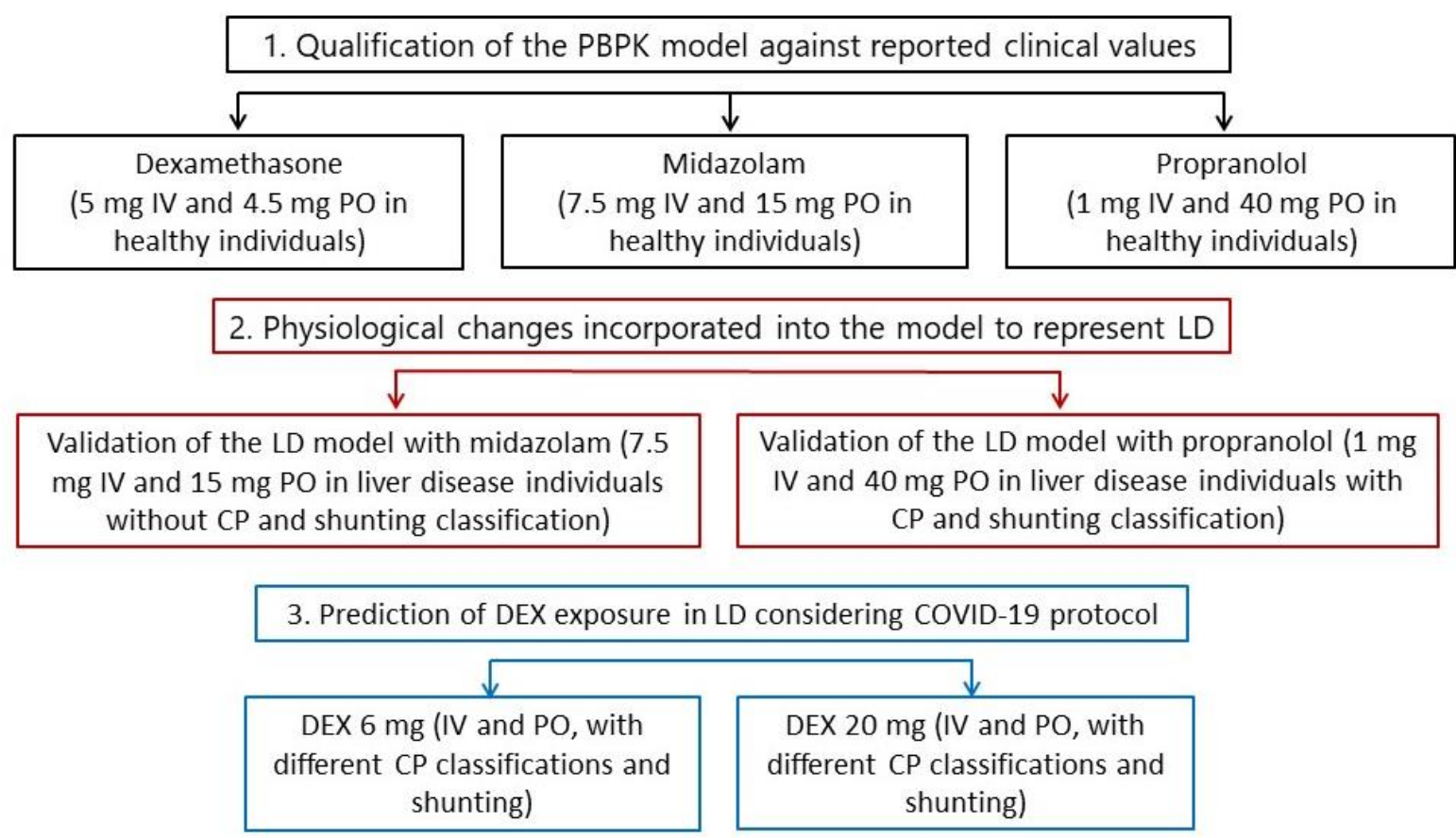

Figure 1. Overall step-by-step workflow representing the PBPK modelling qualification and predictions. IV, intravenous. PO, oral. LD, liver disease. CP, Child-Pugh. DEX, dexamethasone. 

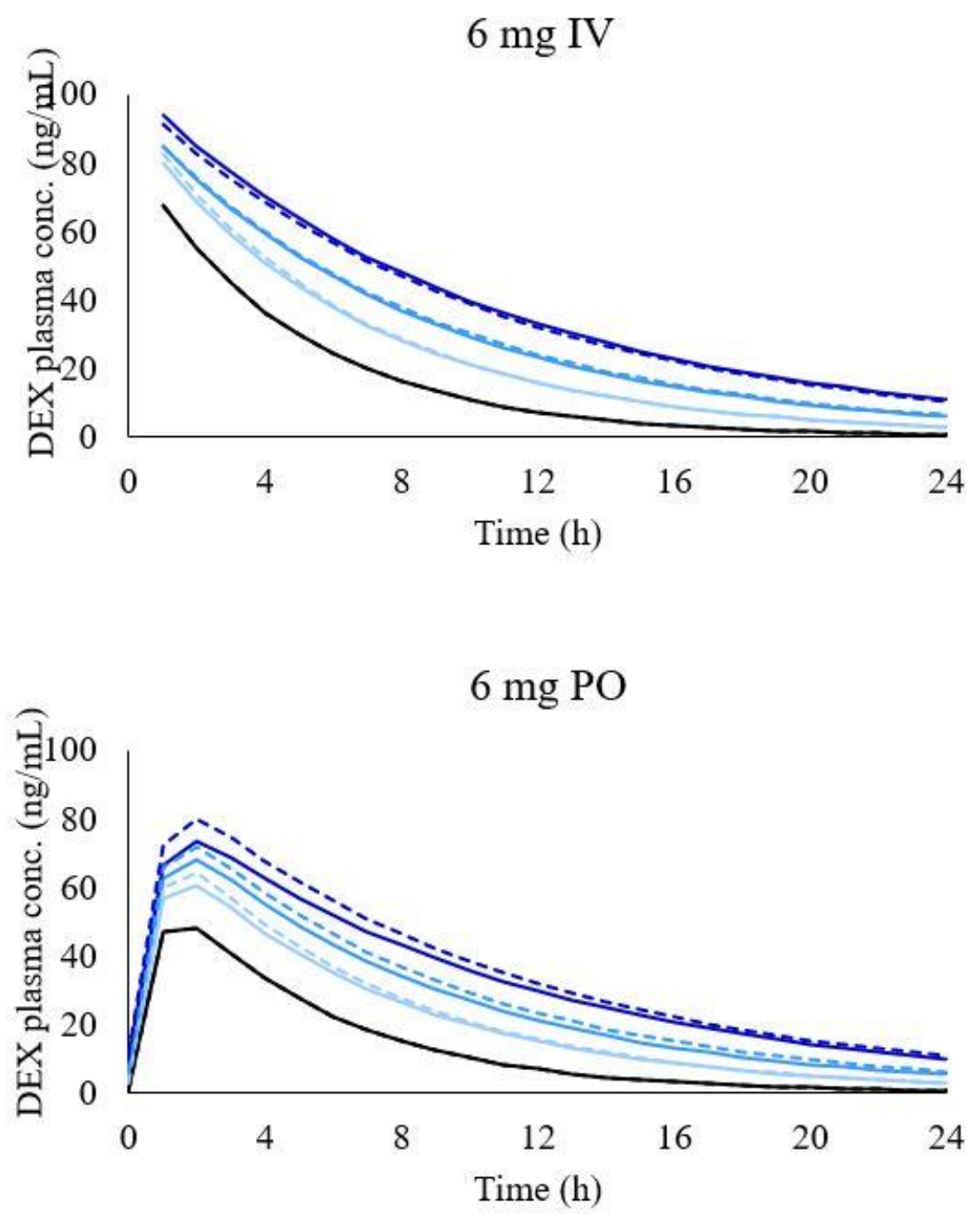

Figure 2. Simulated concentration-time profile of DEX in different LD conditions after $6 \mathrm{mg}$ intravenous administration (graph on the top) and $6 \mathrm{mg}$ oral administration (graph on the bottom). Black line, healthy individuals. Light blue line, CP-A condition, blue line, CP-B condition, and dark-blue line, CP-C condition. Dashed lines represent simulations with shunting and solid lines with no shunting. 
medRxiv preprint doi: https://doi.org/10.1101/2021.11.10.21266141; this version posted November 10, 2021. The copyright holder for this preprint (which was not certified by peer review) is the author/funder, who has granted medRxiv a license to display the preprint in

It is made available under a CC-BY 4.0 International license.

Table 1. Physiological and biochemical parameter changes in the liver disease model according to $\mathrm{CP}$ score (A, B, C). Johnson's reported values. ${ }^{3}$

\begin{tabular}{lllll}
\hline \multirow{2}{*}{ Parameters } & & \multicolumn{3}{c}{ CP score } \\
\cline { 3 - 5 } & Control & $\mathrm{A}$ & $\mathrm{B}$ & $\mathrm{C}$ \\
\hline $\mathrm{Qpv}^{*}$ & 1.00 & 0.91 & 0.63 & 0.55 \\
$\mathrm{Qha}^{*}$ & 1.00 & 1.40 & 1.62 & 1.91 \\
$\mathrm{Q}_{\mathrm{cc}}{ }^{*}$ & 1.00 & 1.16 & 1.32 & 1.40 \\
$\mathrm{Q}^{*}$ & 1.00 & 1.00 & 1.00 & 1.00 \\
$\mathrm{CL}_{\text {int,CYP3A4 }}{ }^{*}$ & 1.00 & 0.59 & 0.39 & 0.25 \\
$\mathrm{CL}_{\text {int,CYP1A2 }}{ }^{*}$ & 1.00 & 0.63 & 0.26 & 0.12 \\
$\mathrm{CL}_{\text {int,CYP2D6 }}{ }^{*}$ & 1.00 & 0.76 & 0.33 & 0.11 \\
$\mathrm{CL}_{\text {int,CYP2C19 }}{ }^{*}$ & 1.00 & 0.32 & 0.26 & 0.12 \\
$\mathrm{CL}_{\text {int,UGT }}$ & 1.00 & 1.00 & 1.00 & 1.00 \\
AbCYP3A4,gut $^{*}$ & 1.00 & 0.84 & 0.57 & 0.35 \\
Albumin $\left.{ }^{*} \mathrm{~g} / \mathrm{L}\right)$ & 44.70 & 41.10 & 33.90 & 26.30 \\
$\mathrm{~W}_{\text {liver }}{ }^{*}$ & 1.00 & 0.81 & 0.65 & 0.53 \\
GFR $^{*}$ & 1.00 & 0.76 & 0.63 & 0.60
\end{tabular}

*Values are a fraction of the control. $\mathrm{CL}_{\text {int, }}$ intrinsic clearance of specific enzyme. AbCYP3A4,gut, abundance of CYP3A4 in the intestinal tissue. $\mathrm{Q}_{\mathrm{cc}}$, cardiac output. Qha, blood flow of the hepatic artery. $\mathrm{Q}_{\mathrm{pv}}$, blood flow of the portal vein. Q, blood flow of other organs. $\mathrm{W}_{\text {liver, }}$, weight of the liver. 
medRxiv preprint doi: https://doi.org/10.1101/2021.11.10.21266141; this version posted November 10,2021 . The copyright holder for this preprint (which was not certified by peer review) is the author/funder, who has granted medRxiv a license to display the preprint in

It is made available under a CC-BY 4.0 International license.

Table 2. Physiochemical and pharmacokinetic characteristics of dexamethasone, midazolam, and propranolol.

\begin{tabular}{|c|c|c|c|}
\hline Parameter & Dexamethasone & Midazolam & Propranolol \\
\hline \multicolumn{4}{|l|}{ Physiochemical } \\
\hline Molecular weight (g/mol) & $392.46^{7}$ & $325.77^{25}$ & $259.34^{49}$ \\
\hline$f_{\text {up }}$ & $0.23^{7}$ & $0.03^{25}$ & $0.1^{49}$ \\
\hline$f_{\text {ugut }}$ & 1 & 1 & 1 \\
\hline $\log \mathrm{P}$ & $1.83^{9}$ & $3.89^{25}$ & $3.48^{49}$ \\
\hline pKa (basic) & $12.42^{7}$ & $6.57^{25}$ & $9.5^{49}$ \\
\hline $\mathrm{R}$ & $0.93^{35}$ & $0.55^{29}$ & $0.76^{49}$ \\
\hline$K_{\mathrm{a}}\left(\mathrm{h}^{-1}\right)$ & $1.9^{9}$ & $3.18^{50}$ & - \\
\hline$P_{\text {eff }}\left(10^{-4} \mathrm{~cm} / \mathrm{s}\right)$ & - & - & $3.5^{51}$ \\
\hline \multicolumn{4}{|l|}{ Metabolism } \\
\hline $\mathrm{CL}_{\text {int,CYP3A4gut }}(\mu \mathrm{L} / \mathrm{min} / \mathrm{pmol})$ & $0.12^{9}$ & $1.7^{18}$ & - \\
\hline CLint,CYP3A4liver $(\mu \mathrm{L} / \mathrm{min} / \mathrm{pmol})$ & $0.12^{9}$ & $2.7^{17}$ & - \\
\hline $\mathrm{CL}_{\text {int,CYP1A2liver }}(\mu \mathrm{L} / \mathrm{min} / \mathrm{pmol})$ & - & - & $1.76^{52}$ \\
\hline $\mathrm{CL}_{\text {int,CYP2D6liver }}(\mu \mathrm{L} / \mathrm{min} / \mathrm{pmol})$ & - & - & $31.6^{52}$ \\
\hline $\mathrm{CL}_{\text {int,CYP2C19gut }}(\mu \mathrm{L} / \mathrm{min} / \mathrm{pmol})$ & - & - & $0.729^{53}$ \\
\hline $\mathrm{CL}_{\text {int,CYP2C19liver }}(\mu \mathrm{L} / \mathrm{min} / \mathrm{pmol})$ & - & - & $0.729^{53}$ \\
\hline $\mathrm{CL}_{\text {int,UGTliver }}(\mu \mathrm{L} / \mathrm{min} / \mathrm{mg})$ & - & - & $70.6^{52}$ \\
\hline \multicolumn{4}{|l|}{ CYP3A4 induction } \\
\hline $\mathrm{E}_{\max }$ & $6.6^{54}$ & - & - \\
\hline $\mathrm{EC}_{50}(\mu \mathrm{M})$ & $51.22^{54}$ & - & - \\
\hline \multicolumn{4}{|l|}{ Distribution } \\
\hline $\mathrm{Vd}$ correction factor & 0.6 & 0.2 & - \\
\hline \multicolumn{4}{|l|}{ Elimination } \\
\hline $\mathrm{CL}_{\text {renal }}(\mathrm{L} / \mathrm{h})$ & $1.57^{30}$ & & \\
\hline
\end{tabular}

$f_{\text {up }}$, fraction of drug unbound in plasma. $f_{\text {ugut }}$, fraction of drug unbound in the gut. $\log$, partition coefficient between water and octanol. pKa, acid dissociation constant. R, blood to plasma ratio. $K_{\mathrm{a}}$, absorption constant rate. $\mathrm{P}_{\text {eff, }}$ effective permeability. $\mathrm{CL}_{\text {int, }}$, intrinsic clearance. CYP, cytochrome P450. UGT, UDP-glucuronosyltransferases. EC $_{50}$ concentration of inducer producing $50 \%$ of maximum induction, $\mathrm{E}_{\max }$ maximum induction. $\mathrm{Vd}$, volume of distribution. $\mathrm{CL}_{\text {renal, }}$, renal clearance. 
Table 3. Qualification of the PBPK model in healthy and liver disease individuals for midazolam, propranolol, and dexamethasone.

\begin{tabular}{|c|c|c|c|c|c|c|c|c|}
\hline \multirow[t]{2}{*}{ Population } & \multicolumn{4}{|l|}{ MDZ 7.5 mg IV } & \multicolumn{4}{|l|}{ MDZ 15 mg oral } \\
\hline & Variables & Observed & Predicted & AFE & Variables & Observed & Predicted & AFE \\
\hline \multirow[t]{3}{*}{ Healthy } & $\mathrm{AUC}_{0}$-inf $(\mathrm{ng} \cdot \mathrm{h} / \mathrm{mL})$ & $298^{31}$ & 304.45 & 1.02 & $\mathrm{AUC}_{0 \text {-inf }}(\mathrm{ng} \cdot \mathrm{h} / \mathrm{mL})$ & $362^{31}$ & 260.50 & 1.39 \\
\hline & $\mathrm{t}_{1 / 2}(\mathrm{~h})$ & $3.8^{31}$ & 3.32 & 1.15 & $\mathrm{C}_{\max }(\mathrm{ng} / \mathrm{mL})$ & $62.83^{31}$ & 54.66 & 1.15 \\
\hline & $\mathrm{CL}(\mathrm{mL} / \mathrm{h} / \mathrm{kg})$ & $337.8^{31}$ & 328.46 & 1.03 & $t_{\max }(h)$ & $0.75^{31}$ & 0.75 & 1.00 \\
\hline \multirow[t]{4}{*}{$L D$} & $\mathrm{AUC}_{0-\text { inf }}(\mathrm{ng} \cdot \mathrm{h} / \mathrm{mL})$ & $543^{31}$ & 468.39 & 1.16 & $\mathrm{AUC}_{0-\text {-inf }}(\mathrm{ng} \cdot \mathrm{h} / \mathrm{mL})$ & $576^{31}$ & 451.29 & 1.28 \\
\hline & $\mathrm{t}_{1 / 2}(\mathrm{~h})$ & $7.36^{31}$ & 5.06 & 1.45 & $\mathrm{C}_{\max }(\mathrm{ng} / \mathrm{mL})$ & $96.86^{31}$ & 69.88 & 1.39 \\
\hline & $\mathrm{CL}(\mathrm{mL} / \mathrm{h} / \mathrm{kg})$ & $200.4^{31}$ & 213.50 & 1.07 & $t_{\max }(h)$ & $0.75^{31}$ & 0.75 & 1.00 \\
\hline & PRO $1 \mathrm{mg}$ IV & & & & PRO $40 \mathrm{mg}$ oral & & & \\
\hline \multirow[t]{3}{*}{ Healthy } & $\mathrm{AUC}_{0 \text {-inf }}(\mathrm{ng} \cdot \mathrm{min} / \mathrm{mL})$ & $979^{32}$ & 1166.01 & 1.19 & $\mathrm{AUC}_{0-\text { inf }}(\mathrm{ng} \cdot \mathrm{min} / \mathrm{mL})$ & $8930^{32}$ & 10907.92 & 1.22 \\
\hline & $\mathrm{t}_{1 / 2}(\min )$ & $205^{32}$ & 312.63 & 1.53 & $\mathrm{C}_{\max }(\mathrm{ng} / \mathrm{mL})$ & $28^{32}$ & 23.73 & 1.18 \\
\hline & $\mathrm{CL}(\mathrm{mL} / \mathrm{min})$ & $1187^{32}$ & 857.62 & 1.38 & $\mathrm{t}_{\max }(\min )$ & $180^{32}$ & 120.00 & 1.50 \\
\hline \multirow[t]{4}{*}{$L D$} & $\mathrm{AUC}_{0 \text {-inf }}(\mathrm{ng} \cdot \mathrm{min} / \mathrm{mL})$ & $1778^{32}$ & 1676 & 1.06 & $\mathrm{AUC}_{0 \text {-inf }}(\mathrm{ng} \cdot \mathrm{min} / \mathrm{mL})$ & $47260^{32}$ & 34258 & 1.38 \\
\hline & $\mathrm{t}_{1 / 2}(\min )$ & $641^{32}$ & 398 & 1.61 & $\mathrm{C}_{\max }(\mathrm{ng} / \mathrm{mL})$ & $65^{32}$ & 60 & 1.08 \\
\hline & $\mathrm{CL}(\mathrm{mL} / \mathrm{min})$ & $833^{32}$ & 597 & 1.40 & $\mathrm{t}_{\max }(\min )$ & $180^{32}$ & 120 & 1.50 \\
\hline & DEXA 5 mg IV & & & & DEXA $4.5 \mathrm{mg}$ oral & & & \\
\hline \multirow[t]{4}{*}{ Healthy } & $\mathrm{AUC}_{0-\text { inf }}(\mathrm{ng} \cdot \mathrm{h} / \mathrm{mL})$ & $246^{35}$ & 216.13 & 1.14 & $\mathrm{AUC}_{0 \text {-inf }}(\mathrm{ng} \cdot \mathrm{h} / \mathrm{mL})$ & $239^{35}$ & 238.15 & 1.00 \\
\hline & $\mathrm{t}_{1 / 2}(\mathrm{~h})$ & $4.1^{35}$ & 3.58 & 1.15 & $\mathrm{C}_{\max }(\mathrm{ng} / \mathrm{mL})$ & $38^{35}$ & 34.64 & 1.09 \\
\hline & $\mathrm{CL}(\mathrm{mL} / \mathrm{h} / \mathrm{kg})$ & $243^{35}$ & 330.49 & 1.36 & $\mathrm{t}_{\max }(\mathrm{h})$ & $2^{35}$ & 2.00 & 1.10 \\
\hline & $\mathrm{Vd}(\mathrm{L} / \mathrm{kg})$ & $1.4^{35}$ & 1.71 & 1.22 & $\mathrm{t}_{1 / 2}(\mathrm{~h})$ & $4^{35}$ & 3.59 & 1.11 \\
\hline
\end{tabular}


Data are presented as the mean as described in section methods-model qualification. MDZ, midazolam. PRO, propranolol. DEXA, dexamethasone. $\mathrm{AUC}_{0 \text {-inf, }}$, area under the plasma concentration-time curve over a dosing interval. $\mathrm{C}_{\max }$ maximum plasma concentration. $\mathrm{t}_{1 / 2}$, half-life time. $\mathrm{CL}$, clearance. $t_{\max }$, time to maximum plasma concentration. $\mathrm{Vd}$, volume of distribution. LD, liver dysfunction. AFE, average fold error. 
Table 4. Predictions of dexamethasone pharmacokinetics in virtual populations with varying degrees of liver disease.

\begin{tabular}{|c|c|c|c|c|c|c|c|}
\hline \multirow{2}{*}{ Parameters } & \multirow{2}{*}{ Description } & \multicolumn{3}{|c|}{ IV Dose (6 mg) } & \multicolumn{3}{|c|}{ Oral Dose (6 mg) } \\
\hline & & $\mathrm{CP}-\mathrm{A}$ & CP-B & $\mathrm{CP}-\mathrm{C}$ & $\mathrm{CP}-\mathrm{A}$ & $\mathrm{CP}-\mathrm{B}$ & $\mathrm{CP}-\mathrm{C}$ \\
\hline \multirow[t]{4}{*}{$\mathrm{AUC}_{0-24}$} & No Shunting & $141.37(18)$ & $201.24(15)$ & $315.77(16)$ & $127(20)$ & $180.20(19)$ & $277.08(16)$ \\
\hline & Ratio (No Shunting/Healthy) & 1.68 & 2.39 & 3.74 & 1.72 & 2.44 & 3.76 \\
\hline & Shunting & $144.24(19)$ & $204.96(17)$ & $307.63(15)$ & $133.29(18)$ & $194.81(18)$ & $298.97(17)$ \\
\hline & Ratio (Shunting/Healthy) & 1.71 & 2.43 & 3.65 & 1.81 & 2.64 & 4.06 \\
\hline \multirow[t]{5}{*}{ CL } & No Shunting & $10.60(19)$ & $8.34(16)$ & $6.45(17)$ & $11.80(20)$ & $9.31(19)$ & $7.35(16)$ \\
\hline & Ratio (No Shunting/Healthy) & 0.65 & 0.51 & 0.39 & 0.63 & 0.50 & 0.39 \\
\hline & Shunting & $10.39(20)$ & $8.19(18)$ & $6.62(15)$ & $11.25(18)$ & $8.62(18)$ & $6.82(17)$ \\
\hline & Ratio (Shunting/Healthy) & 0.64 & 0.50 & 0.40 & 0.60 & 0.46 & 0.36 \\
\hline & & \multicolumn{3}{|c|}{ IV Dose (20 mg) } & \multicolumn{3}{|c|}{ Oral Dose (20 mg) } \\
\hline \multirow[t]{2}{*}{$\mathrm{AUC}_{0-24}$} & No Shunting & $459.50(17)$ & $669.14(17)$ & $997.97(17)$ & $419.20(20)$ & $596.94(20)$ & $894.69(20)$ \\
\hline & Ratio (No Shunting/Healthy) & 1.68 & 2.44 & 3.65 & 1.73 & 2.47 & 3.70 \\
\hline \multirow[t]{2}{*}{$\mathrm{CL}$} & No Shunting & $10.87(18)$ & $8.36(17)$ & $6.81(18)$ & $11.92(20)$ & $9.37(20)$ & $7.59(20)$ \\
\hline & Ratio (No Shunting/Healthy) & 0.65 & 0.50 & 0.41 & 0.63 & 0.49 & 0.40 \\
\hline
\end{tabular}

Data are presented as the mean (coefficient of variation, \%). AUC0-24, area under the plasma concentration-time curve over a dosing interval considering fraction of drug unbound to protein $(\mathrm{ng} \cdot \mathrm{h} / \mathrm{mL})$. CL, clearance $(\mathrm{L} / \mathrm{h}) . \mathrm{CP}-\mathrm{A}, \mathrm{CP}-\mathrm{B}$ and CP-C correspond to the Child-Pugh score. 
medRxiv preprint doi: https://doi.org/10.1101/2021.11.10.21266141; this version posted November 10,2021 . The copyright holder for this preprint (which was not certified by peer review) is the author/funder, who has granted medRxiv a license to display the preprint in

It is made available under a CC-BY 4.0 International license.

\section{REFERENCES}

1. Qiu P, Zhou Y, Wang F, et al. Clinical characteristics, laboratory outcome characteristics, comorbidities, and complications of related COVID-19 deceased: a systematic review and meta-analysis. Aging Clin Exp Res. 2020;32(9):1869-1878.

2. Kovalic AJ, Satapathy SK, Thuluvath PJ. Prevalence of chronic liver disease in patients with COVID-19 and their clinical outcomes: a systematic review and meta-analysis. Hepatol Int. 2020;14(5):612-620.

3. Johnson TN, Boussery K, Rowland-Yeo K, Tucker GT, Rostami-Hodjegan A. A semimechanistic model to predict the effects of liver cirrhosis on drug clearance. Clin Pharmacokinet. 2010;49(3):189-206.

4. Schuppan D, Afdhal H N. Liver cirrhosis. The Lancet. 2008;371(9615):838-851.

5. Edginton AN, Willmann S. Physiology-based simulations of a pathological condition: prediction of pharmacokinetics in patients with liver cirrhosis. Clin Pharmacokinet. 2008;47(11):743-752.

6. Rodighiero V. Effects of liver disease on pharmacokinetics. An update. Clin Pharmacokinet. 1999;37(5):399-431.

7. DrugBank. Dexamethasone. Available at: https://go.drugbank.com/drugs/DB01234.

8. Matthay MA, Thompson BT. Dexamethasone in hospitalised patients with COVID-19: addressing uncertainties. Lancet Respir Med. 2020;8(12):1170-1172.

9. $\mathrm{Ke} \mathrm{AB}$, Milad MA. Evaluation of Maternal Drug Exposure Following the Administration of Antenatal Corticosteroids During Late Pregnancy Using Physiologically-Based Pharmacokinetic Modeling. Clin Pharmacol Ther. 2019;106(1):164-173.

10. Pilla Reddy V, Walker M, Sharma P, Ballard P, Vishwanathan K. Development, Verification, and Prediction of Osimertinib Drug-Drug Interactions Using PBPK Modeling Approach to Inform Drug Label. CPT Pharmacometrics Syst Pharmacol. 2018;7(5):321-330.

11. Kawai S, Ichikawa Y, Homma M. Differences in metabolic properties among cortisol, prednisolone, and dexamethasone in liver and renal diseases: accelerated metabolism of dexamethasone in renal failure. J Clin Endocrinol Metab. 1985;60(5):848-854.

12. Grimstein M, Yang Y, Zhang X, et al. Physiologically Based Pharmacokinetic Modeling in Regulatory Science: An Update From the U.S. Food and Drug Administration's Office of Clinical Pharmacology. J Pharm Sci. 2019;108(1):21-25.

13. de la Grandmaison GL, Clairand I, Durigon M. Organ weight in 684 adult autopsies: new tables for a Caucasoid population. Forensic Sci Int. 2001;119(2):149-154.

14. Bosgra S, van Eijkeren J, Bos P, Zeilmaker M, Slob W. An improved model to predict physiologically based model parameters and their inter-individual variability from anthropometry. Crit Rev Toxicol. 2012;42(9):751-767.

15. Brown RP, Delp MD, Lindstedt SL, Rhomberg LR, Beliles RP. Physiological parameter values for physiologically based pharmacokinetic models. Toxicol Ind Health. 1997;13(4):407-484.

16. Birnbaum L, Brown R, Bischoff K, et al. Physiological parameter values for PBPK models.International Life Sciences Institute, Risk Science Institute, Washington, DC. In:1994.

17. Gertz M, Harrison A, Houston JB, Galetin A. Prediction of human intestinal first-pass metabolism of 25 CYP3A substrates from in vitro clearance and permeability data. Drug Metab Dispos. 2010;38(7):1147-1158. 
medRxiv preprint doi: https://doi.org/10.1101/2021.11.10.21266141; this version posted November 10,2021 . The copyright holder for this preprint (which was not certified by peer review) is the author/funder, who has granted medRxiv a license to display the preprint in

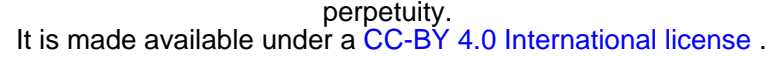

18. Paine MF, Khalighi M, Fisher JM, et al. Characterization of interintestinal and intraintestinal variations in human CYP3A-dependent metabolism. J Pharmacol Exp Ther. 1997;283(3):1552-1562.

19. Paine MF, Hart HL, Ludington SS, Haining RL, Rettie AE, Zeldin DC. The human intestinal cytochrome P450 "pie". Drug Metab Dispos. 2006;34(5):880-886.

20. Thelen K, Dressman JB. Cytochrome P450-mediated metabolism in the human gut wall. J Pharm Pharmacol. 2009;61(5):541-558.

21. Yu LX, Amidon GL. A compartmental absorption and transit model for estimating oral drug absorption. Int J Pharm. 1999;186(2):119-125.

22. Emoto C, Fukuda T, Venkatasubramanian R, Vinks AA. The impact of CYP3A5*3 polymorphism on sirolimus pharmacokinetics: insights from predictions with a physiologically-based pharmacokinetic model. Br J Clin Pharmacol. 2015;80(6):14381446.

23. Achour B, Russell MR, Barber J, Rostami-Hodjegan A. Simultaneous quantification of the abundance of several cytochrome P450 and uridine 5'-diphosphoglucuronosyltransferase enzymes in human liver microsomes using multiplexed targeted proteomics. Drug Metab Dispos. 2014;42(4):500-510.

24. Lasker JM, Wester MR, Aramsombatdee E, Raucy JL. Characterization of CYP2C19 and CYP2C9 from human liver: respective roles in microsomal tolbutamide, Smephenytoin, and omeprazole hydroxylations. Arch Biochem Biophys. 1998;353(1):16-28.

25. Barter ZE, Chowdry JE, Harlow JR, Snawder JE, Lipscomb JC, Rostami-Hodjegan A. Covariation of human microsomal protein per gram of liver with age: absence of influence of operator and sample storage may justify interlaboratory data pooling. Drug Metab Dispos. 2008;36(12):2405-2409.

26. Simón-Talero M, Roccarina D, Martínez J, et al. Association Between Portosystemic Shunts and Increased Complications and Mortality in Patients With Cirrhosis. Gastroenterology. 2018;154(6):1694-1705.e1694.

27. Ohkubo H, Okuda K, Iida S, Ohnishi K, Ikawa S, Makino I. Role of portal and splenic vein shunts and impaired hepatic extraction in the elevated serum bile acids in liver cirrhosis. Gastroenterology. 1984;86(3):514-520.

28. Poulin P, Theil FP. Prediction of pharmacokinetics prior to in vivo studies. 1. Mechanism-based prediction of volume of distribution. J Pharm Sci. 2002;91(1):129156.

29. DrugBank. Midazolam. Available at: https://go.drugbank.com/drugs/DB00683.

30. HEMADY (dexamethasone tablets). US prescribing information.

31. Pentikäinen PJ, Välisalmi L, Himberg JJ, Crevoisier C. Pharmacokinetics of midazolam following intravenous and oral administration in patients with chronic liver disease and in healthy subjects. J Clin Pharmacol. 1989;29(3):272-277.

32. Taegtmeyer AB, Haschke M, Tchambaz L, et al. A study of the relationship between serum bile acids and propranolol pharmacokinetics and pharmacodynamics in patients with liver cirrhosis and in healthy controls. PLoS One. 2014;9(6):e97885.

33. EMA. Guideline on the qualification and reporting of physiologically based pharmacokinetic (PBPK) modelling and simulation. Available at: https://www.ema.europa.eu/en/documents/scientific-guideline/draft-guidelinequalification-reporting-physiologically-based-pharmacokinetic-pbpkmodelling_en.pdf. Accessed: 10/06/2020.

34. Abduljalil K, Cain T, Humphries H, Rostami-Hodjegan A. Deciding on success criteria for predictability of pharmacokinetic parameters from in vitro studies: an analysis based on in vivo observations. Drug Metab Dispos. 2014;42(9):1478-1484. 
medRxiv preprint doi: https://doi.org/10.1101/2021.11.10.21266141; this version posted November 10,2021 . The copyright holder for this preprint (which was not certified by peer review) is the author/funder, who has granted medRxiv a license to display the preprint in

It is made available under a CC-BY 4.0 International license .

35. Varis T, Kivistö KT, Backman JT, Neuvonen PJ. The cytochrome P450 3A4 inhibitor itraconazole markedly increases the plasma concentrations of dexamethasone and enhances its adrenal-suppressant effect. Clin Pharmacol Ther. 2000;68(5):487-494.

36. The National Institute for Health and Care Excellence (NICE). COVID-19 rapid guideline: Managing COVID-19. Available at: https://www.nice.org.uk/guidance/ng191/resources/covid19-rapid-guidelinemanaging-covid19-pdf-51035553326.

37. Vecchié A, Batticciotto A, Tangianu F, et al. High-dose dexamethasone treatment for COVID-19 severe acute respiratory distress syndrome: a retrospective study. Intern Emerg Med. 2021.

38. FDA. Guidance for industry: pharmacokinetics in patients with impaired hepatic function: study design, data analysis, and impact on dosing and labelling. Available at: https://www.fda.gov/media/71311/download.

39. EMA. Guideline on the evaluation of the pharmacokinetics of medicinal products in patients with impaired hepatic function. Available at: https://www.ema.europa.eu/en/evaluation-pharmacokinetics-medicinal-productspatients-impaired-hepatic-function.

40. Verbeeck RK. Pharmacokinetics and dosage adjustment in patients with hepatic dysfunction. Eur J Clin Pharmacol. 2008;64(12):1147-1161.

41. Wu R, Wang L, Kuo HD, et al. An Update on Current Therapeutic Drugs Treating COVID-19. Curr Pharmacol Rep. 2020:1-15.

42. Venisse N, Peytavin G, Bouchet S, et al. Concerns about pharmacokinetic (PK) and pharmacokinetic-pharmacodynamic (PK-PD) studies in the new therapeutic area of COVID-19 infection. Antiviral Res. 2020;181:104866.

43. Simon F, Garcia J, Guyot L, et al. Impact of Interleukin-6 on Drug-Metabolizing Enzymes and Transporters in Intestinal Cells. AAPS J. 2019;22(1):16.

44. Simon F, Gautier-Veyret E, Truffot A, et al. Modeling Approach to Predict the Impact of Inflammation on the Pharmacokinetics of CYP2C19 and CYP3A4 Substrates. Pharm Res. 2021;38(3):415-428.

45. Dickmann LJ, Patel SK, Rock DA, Wienkers LC, Slatter JG. Effects of interleukin-6 (IL-6) and an anti-IL-6 monoclonal antibody on drug-metabolizing enzymes in human hepatocyte culture. Drug Metab Dispos. 2011;39(8):1415-1422.

46. ACTEMRA® (tocilizumab). US prescribing information.

47. Ciriaco M, Ventrice $\mathrm{P}$, Russo $\mathrm{G}$, et al. Corticosteroid-related central nervous system side effects. J Pharmacol Pharmacother. 2013;4(Suppl 1):S94-98.

48. Castleden CM, Kaye CM, Parsons RL. The effect of age on plasma levels of propranolol and practolol in man. Br J Clin Pharmacol. 1975;2(4):303-306.

49. DrugBank. Propranolol. Available at: https://go.drugbank.com/drugs/DB00571.

50. van Rongen A, Kervezee L, Brill M, et al. Population Pharmacokinetic Model Characterizing 24-Hour Variation in the Pharmacokinetics of Oral and Intravenous Midazolam in Healthy Volunteers. CPT Pharmacometrics Syst Pharmacol. 2015;4(8):454-464.

51. Akabane T, Tabata K, Kadono K, Sakuda S, Terashita S, Teramura T. A comparison of pharmacokinetics between humans and monkeys. Drug Metab Dispos. 2010;38(2):308-316.

52. Li M, Zhu L, Chen L, Li N, Qi F. Assessment of drug-drug interactions between voriconazole and glucocorticoids. J Chemother. 2018;30(5):296-303.

53. Rose RH, Turner DB, Neuhoff S, Jamei M. Incorporation of the Time-Varying Postprandial Increase in Splanchnic Blood Flow into a PBPK Model to Predict the 
medRxiv preprint doi: https://doi.org/10.1101/2021.11.10.21266141; this version posted November 10, 2021. The copyright holder for this preprint (which was not certified by peer review) is the author/funder, who has granted medRxiv a license to display the preprint in It is made available under a CC-BY 4.0 International license .

Effect of Food on the Pharmacokinetics of Orally Administered High-Extraction Drugs. AAPS J. 2017;19(4):1205-1217.

54. Rihani BAS, Deodhar M, Dow P, Turgeon J, Michaud V. Is Dexamethasone a Substrate, an Inducer, or a Substrate-Inducer of CYP3As? Archives of Pharmacy \& Pharmacology Research. 2020. 